\title{
ТРАНСПАРЕНТНОСТЬ В АРБИТРАЖНОМ ПРОЦЕССЕ
}

\author{
(c) 2021 Лошкарев Андрей Викторович \\ доцент, кандидат юридических наук \\ Самарский государственный экономический университет, Россия, Самара \\ E-mail:2482337@mail.ru \\ (c) 2021 Ивенская Анастасия Андреевна \\ магистрант института права \\ Самарский государственный экономический университет, Россия, Самара \\ E-mail: anastasiya141999@mail.ru \\ (c) 2021 Штапаков Матвей Игоревич \\ магистр института права \\ Самарский государственный экономический университет, Россия, Самара \\ E-mail:Matveksh@mail.ru
}

В статье рассматривается принцип транспарентности в арбитражном процессе, дается его определение. Выявляются особенности реализации принципа в арбитражном процессе на разных стадиях судопроизводства.

Ключевые слова: транспарентность, гласность, суд, судопроизводство, правосудие, арбитражный процесс.

Транспарентность (от англ. transparency способность пропускать свет, прозрачность) означает открытость, честность, прозрачность, откровенность*.

Данный принцип появился благодаря судебной реформе 1864 года, которая сделала суд устным и гласным. До реформы гласность в суде отсутствовала, в связи с чем в суде отсутствовал публика, состязание сторон; существовала канцелярская тайна, неизвестность доказательств и невозможность возразить на доказательства противоположной стороны. Неотъемлемой часть судопроизводства являлись следственный процесс, тайный процесс, а также отсутствовал контроль со стороны общества за судопроизводством.

С древних времен в понятие «гласность» вложен глубокий смысл, который можно обозначить как речь, глагол, действие в стремлении установить ясность, известность и имеет достижение как итог.

«... необходимо использовать любые вновь появляющиеся возможности для расширения возможностей и средств доказывания**». Именно поэтому сегодня гласность во многом осуществляется посредством информатизации деятельности судебной системы, и ее развитие в этом направлении должно способствовать воспитанию правосознания.

Указанный принцип закреплен в части 1 статьи 123 Конституции Российской Федерации (далее - Конституция РФ), и, соответственно, принцип гласности реализуется при рассмотрении дела в суде первой, апелляционной, кассационной и надзорной инстанций.

ЛангП.П. трактует о том, что «право как социальное явление, как объект юриспруденции имеет множество сторон, изучаемых соответствующими юридическими науками****». Но поскольку сама норма права, в большей степени, характеризуется как абстрактное явление, которое лишь определяет наиболее типичные нормы поведения, то на практике суд толкует эту норму права от общего явления к частному при уста-

\footnotetext{
* Murrey J., Bradley H., Creigie W., Tolkien J. Oxford English Dictionary // URL: https://languages.oup.com (дата обращения: 13.09.2021).

** Ланг П.П., Лошкарев А.В., Калашникова Е.Б., Середкина О.А. Электронные доказательства в гражданском судопроизводстве // Вопросы экономики и права. 2020. № 3 (141). С. 12.

*** Ланг П.П. Элементная структура юридического процесса // Юридический процесс. 2013. С. 49.
} 
новлении обстоятельств дела.

Таким образом, судебное производство предоставляет гражданам разъясненное и понятное толкование нормы права.

Современные граждане зачастую не могут самостоятельно достигнуть полной реализации своего права, в связи с чем возникает необходимость обратиться к органам, отправляющим правосудие. В данном случае именно толкование нормы права судом является процессом ее реализации.

Современное законодательство совершенствуется благодаря развитию судебной практики, которая служит основой судебной статистики. Судебная практика и статистика, в свою очередь, являются основой законодательной деятельности.

Судебная статистика ведется с целью обеспечения Верховного Суда Российской Федерации и Судебного департамента, его структурных подразделений, включая территориальные органы Судебного департамента в субъектах Российской Федерации, судов общей юрисдикции и арбитражных судов, иных органов государственной власти данными, которые необходимы для осуществления законотворческой деятельности, судебно-правовой реформы, анализа и обобщения судебной практики, организационноправового обеспечения деятельности всех судов Российской Федерации, обеспечения открытости и прозрачности судебной деятельности для граждан".

Поскольку «суды в России самостоятельны, отправляют правосудие беспристрастно и независимо**», прозрачность и открытость судебной деятельности для общества может быть достигнута с применением современных технологий в области права и с возможностью определения обществом задач в области использования технологий.
«Только воплотив в повседневную практику жизни общества формулу развития «демократия - человек - технологии», Россия сможет реализовать свои потенциальные возможности и занять достойное место среди ведущих мировых держав ${ }^{* * * *} »$.

Для понимания пределов реализации и содержания принципа гласности в арбитражном процессуальном праве следует отметить правило, которое закреплено в части 7 статьи $11 \mathrm{Ap}-$ битражного процессуального кодекса Российской Федерации (далее - АПК РФ), по которому присутствующие в зале заседания имеют право делать письменные заметки, вести звукозапись. Кино- и фотосъемка, видеозапись, трансляция отправления правосудия в ходе судебного заседания арбитражного суда по радио, телевидению и в информационно-коммуникационной сети Интернет (далее - сеть Интернет) допускаются с разрешения судьи - председательствующего в судебном заседании *****.

В пункте 4 Постановления Пленума Высшего Арбитражного Суда Российской Федерации от 08.10.2012 № 61 «Об обеспечении гласности в арбитражном процессе» (далее - Постановление № 61) разъяснено, что, исходя из части 7 статьи 11 АПК РФ, проведение видеозаписи, киносъемки, фотосъемки, прямой трансляции судебного заседания арбитражного суда по радио или телевидению может быть осуществлено лицами, участвующими в деле, а также присутствующими в судебном заседании гражданами, к ним также относятся представители средств массовой информации (далее - СМИ), с разрешения судьи - председательствующего в судебном заседании ${ }^{* * * * * * * *}$.

По смыслу указанного положения АПК РФ с разрешения судьи - председательствующего в судебном заседании - также допускается прямая трансляция судебного разбирательства в

\footnotetext{
* Федеральный закон от 08.01.1998 № 7-Ф3 «О Судебном департаменте при Верховном Суде Российской Федерации» (ред. от 12.03.2014 № 29-Ф3) // СПС «КонсультантПлюс» (дата обращения: 14.09.2021).

** Ланг П.П.Право на судебную защиту как конституционная ценность // Вопросы экономики и права. 2021. № 6. C. 13.

*** Распоряжение Правительства РФ от 17.11.2008 № 1662-p «О Концепции долгосрочного социальноэкономического развития Российской Федерации на период до 2020 года» // СПС «КонсультантПлюс» (дата обращения: 14.09.2021).

***** Арбитражный процессуальный кодекс Российской Федерации от 24.07.2001 № 95-Ф3 (ред. от 08.12.2020) // СПС «КонсультантПлюс» (дата обращения: 13.09.2021).

******* Постановление Пленума Высшего Арбитражного Суда Российской Федерации от 08.10.2012 № 61 «Об обеспечении гласности в арбитражном процессе» // СПС «КонсультантПлюс» (дата обращения: 14.09.2021).
} 
сети Интернет.

Ходатайство о проведении видеозаписи, киносъемки, фотосъемки, прямой трансляции в зале арбитражного суда по радио, телевидению или в сети Интернет может быть подано участниками процесса в письменной форме, посредством направления в арбитражный суд в электронном виде или же заявлено устно в предварительном судебном заседании или судебном заседании.

В данном случае такое ходатайство разрешается арбитражным судом в порядке, предусмотренном статьей 159 АПК РФ. При этом в ходе судебного заседания судья выясняет мнение участников по делу, которые вправе представить свои возражения. Иные лица, присутствующие в судебном заседании, вправе заявить о своем намерении провести видеозапись, киносъемку, фотосъемку, прямую трансляцию хода судебного заседания арбитражного суда по радио, телевидению или в сети Интернет, в том числе непосредственно в судебном заседании. Заявление таких лиц разрешается судьей, рассматривающим дело, единолично*, либо коллегиально судьями, если порядок рассмотрения дела предусматривает коллегиальный состав.

Произведенная в ходе судебного заседания звукозапись, а также сделанная с разрешения судьи, коллегии судей видеозапись могут быть использованы в дальнейшем без получения согласия судьи ${ }^{* * *}$.

Согласно пунктам 5, 5.1 Постановления № 61 по результатам рассмотрения заявленного участниками дела, иными лицами ходатайства арбитражный суд выносит определение об удовлетворении или об отказе в удовлетворении ходатайства о проведении видеозаписи, киносъемки, фотосъемки или трансляции судебного заседания арбитражного суда по радио, телевидению или в сети Интернет.

Исходя из положений пункта 8 части 2 статьи 155, абзаца 2 части 3 статьи 184 АПК РФ определение об удовлетворении или об отказе в удовлетворении ходатайства о проведении видеозаписи, киносъемки, фотосъемки или трансляции судебного заседания арбитражного суда по радио, телевидению или в сети Интернет может быть либо занесено в протокол судебного заседания, либо вынесено в виде отдельного судебного акта. Если указанное ходатайство подано в арбитражный суд до открытия судебного заседания, оно может быть разрешено судьей в определении о назначении судебного заседания. В таком определении судья указывает наименование СМИ, производящего соответствующие мероприятия, а если съемка осуществляется физическим лицом - данные о его фамилии, имени, отчестве и мотивы вынесения определения.

Согласно статьям 14, 15 Федерального закона от 22.12.2008 № 262-Ф3 «Об обеспечении доступа к информации о деятельности судов в Российской Федерации» в сети Интернет размещаются тексты судебных актов.

Добавление части 8 статьи 11 АПК РФ положения, в которой прописывается, что судебные акты размещаются в сети Интернет на официальном сайте арбитражного суда в государственной автоматизированной системе Российской Федерации «Правосудие» - позволяет каждому гражданину, обратившемуся в суд, формировать представление о современных технологиях в процессе ${ }^{* * * *}$.

Применение технологий в арбитражном судопроизводстве позволяет поднять этот процесс на новый современный уровень с учетом потребностей граждан.

В данный момент, в связи с вводимыми мерами, направленными на противодействие распространению на территории России новой коронавирусной инфекции (COVID-19), у арбитражных судов возникают вполне обоснованные вопросы по порядку судебного разбирательства, движению дела, проведению судебного заседания. Современные вызовы эпидемиологической ситуации требуют сверхбыстрых решений проблем, иногда даже без законодательного вмешательства, поскольку законотворческий процесс является очень длительным.

Таким примером уже может служить режим онлайн-заседания, который на данный момент никак не урегулирован АПК РФ.

Масштабное внедрение информационных

\footnotetext{
* Там же. П.П. 4.1, 4.2. // СПС «КонсультантПлюс» (дата обращения: 14.09.2021).

** Там же. П. 4.3. // СПС «КонсультантПлюс» (дата обращения: 14.09.2021).

*** Арбитражный процессуальный кодекс Российской Федерации от 24.07.2001 № 95-Ф3 (ред. от 08.12.2020) // СПС «КонсультантПлюс» (дата обращения: 13.09.2021).
} 
технологий в сферу отправления правосудия вне всяких сомнений следует положительно оценивать, поскольку это существенно обеспечивает реализацию процессуальной экономии (как времени - оптимизация сроков рассмотрения дела, так и человеческих, экономических ресурсов), доступность правосудия и гласность судопроизводства*.

Также информационные технологии существенно повышают качество отправления правосудия с точки зрения минимизации судейских ошибок при принятии решения ***.

Таким образом, создаются юридические и фактические предпосылки для реального обеспечения гласности, открытости судопроизводства в арбитражных судах. Поэтому транспарентность правосудия обеспечивает его профилактические и воспитательные функции.

Гласность содействуют снижению субъективизма судей и позволяет гражданам убедиться в соблюдении установленных процессуальным законом правовых процедур разбирательства по делу***.

Невозможно не согласиться с мнением, высказанным рядом авторов, о том, что «в настоящее время вопрос об электронном правосудии, о переходе всего судопроизводства в арбитражных судах исключительно на электронную платформу является одним из самых основных и приоритетных ${ }^{* * * * * *}$ ».

Обращения в электронном виде подаются в суды посредством заполнения определенной формы, размещенной на официальных сайтах судов в сети Интернет, в соответствии с порядком подачи документов в электронном виде, в том числе в форме электронного документа, утверждаемым Верховным Судом Российской Федерации, Судебным департаментом при Верховном Суде Российской Федерации в пределах своих полномочий.
Главной такой электронной площадкой является сервис «Мой арбитр» (https://my.arbitr. ru/\#index), включающий вкладки: «Мои данные», «Заявления и жалобы», «Документы по делам», «Банкротство». Имеется возможность размещения как нового документа (иска, заявления), так и документа в рамках дела (например, ходатайства об отложении разбирательства).

По результатам рассмотрения искового заявления судья вправе принять одно из следующих решений: принять исковое заявление к производству, отказать в его принятии, возвратить или оставить исковое заявление без движения. Все эти действия судьи оформляются в виде определения. Подобные процессуальные действия судьей совершаются единолично, в отсутствие публики. Однако все результаты деятельности судьи фиксируются в соответствующих судебных актах (определение, постановление и т.д.). Именно эти документы на данной стадии должны быть доступны участникам судебно процесса. Таким образом, принцип транспорентности действует весьма ограниченно, касаясь только документов, принимаемых на этой стадии.

Исходя из вышеизложенного, можно сделать вывод, что в большей степени принцип транспарентности реализуется именно на стадии судебного разбирательства, при которой стороны, заинтересованные в исходе дела лица и граждане, изъявившие желание присутствовать при рассмотрении дела, вести аудиозапись или же по ходатайству и с соответствующего разрешения судьи - председательствующего в судебном заседании - кино-, фотосъемку, видеозапись, прямую трансляцию судебного заседания арбитражного суда по радио, телевидению и (или) в сети Интернет, имеют возможность беспрепятственно, в установленном АПК РФ порядке, наблюдать за отправлением правосудия.

\footnotetext{
* Lang P. P., Churakova E. N. E-Money as a Financial Instrument in Globalized Economy: Russian Legislation Experience // Lecture Notes in Networks and Systems. 2021. Vol. 160 LNNS. P. 815-821.

** Процессуальное право: общее и частное: учебное пособие / П. П. Ланг, О. С. Скачкова, Е. Н. Чуракова, А. В. Лошкарев.-Самара: Самарский государственный экономический университет, 2020. - 184 с.

*** Ланг П.П.Ценность и экзистенция принципов права // Евразийский юридический журнал. - 2021. № 6 (157). С. 84-87.

**** Ланг П.П., Чугурова Т.В., Котыхова А.А. Проблемы организации делопроизводства в арбитражных судах // Вопросы экономики и права. 2020. № 3 (141). С. 16.
} 


\section{Библиографический список}

1. Абова Т., Ярков В., Брайг Б., Головко Л., Кудрявцева Е., Юдин А., Прокудина Л., Иванов М., Пацация М., Сарбаш С., Тай Ю. Оптимизация гражданского судопроизводства: новый виток? // Событие. Комментарии экспертов. 2017. № 10. С. 20;

2. Бентам И. О судоустройстве / И.Бентам; по французскому изданию Дюмона, изл. А.Книрим. СанктПетербург: Тип. Правительствующего Сената. 1860. С. 222;

3. Зорькин В.Д. Прецедентный характер решений Конституционного Суда Российской Федерации // Журнал российского права. 2004. № 12. С. 76 ;

4. Корня А. Правозащитники пожурили судей: правозащитники раскритиковали предложения Верховного Суда по оптимизации правосудия // Ведомости. 2018. С. 57;

5. Ланг П.П. Ценность и экзистенция принципов права // Евразийский юридический журнал. - 2021. № 6 (157). С. 84-87.

6. Ланг П.П. Право на судебную защиту как конституционная ценность // Вопросы экономики и права. 2021. № 156. С. 11-15.;

7. Ланг П.П. Элементная структура юридического процесса // Юридический процесс. 2013. С. 49;

8. Ланг П.П., Лошкарев А. В., Калашникова Е. Б., Середкина О. А. Электронные доказательства в гражданском судопроизводстве // Вопросы экономики и права. 2020. № 3 (141). С. 12;

9. Ланг П.П., Чугурова Т.В., Котыхова А. А. Проблемы организации делопроизводства в арбитражных судах // Вопросы экономики и права. 2020. № 3 (141). С. 16;

10. Мусин-Пушкин А.И. Правда русская, или Законы великих князей Ярослава Владимировича и Владимира Всеволодовича Мономаха: С приложением древняго оных наречий и слога на употребительные ныне, и с объяснением слов и названий из употребления вышедших / А. И. Мусин-Пушкин, И. П. Елагин, И. Н. Болтин. Санкт-Петербург: Печ. в тип. Святейшего Правительствующего Синода. 1792. С. 100.

11. Пиголкин А. С. Толкование нормативных актов в СССР / А. С. Пиголкин. Москва: Госюриздат. 1962. С. 166;

12. Процессуальное право: общее и частное: учебное пособие / П.П.Ланг, О.С.Скачкова, Е.Н.Чуракова, А. В. Лошкарев.-Самара: Самарский государственный экономический университет, 2020.-184 с.

13. Северский Я.Г. Памятники древнерусского законодательства: Русская правда. Судные грамоты (Псковская и Новгородская) / Я.Г. Северский. Санкт-Петербург: Книжный магазин А. Ф. Цинзерлинга: Тип. В. Безобразова и Комп. 1893. С. 128;

14. Спицын И.Н. Реформа института судебных извещений и вызовов // Арбитражный и гражданский процесс. 2017. № 12. С. 28 ;

15. Туманов Д. А. и др. Законопроект: оптимизация судопроизводства или отказ от правосудия // Законы России: опыт, анализ, практика. 2018. № 2. С. 84;

16. Хабриева Т.Я. Конституционная реформа в современном мире: Монография / Т. Я. Хабриева. Москва: Наука. 2016. С. 320;

17. Черный Э. В. Русско-греческий словарь / Э. В. Черный. Москва: Кн. маг. В. Думнова п.ф. «Насл. бр. Салаевых». 1896. С. 750 ;

18. Шерстюк В. М. Проект закона о внесении изменений и дополнений в гражданское процессуальное законодательство, внесенный постановлением Пленума Верховного Суда РФ от 3.10.2017 № 30 // Вестник гражданского процесса. 2017. № 6. С. 122;

19. Lang P.P., ChurakovaE.N. E-Money as a Financial Instrument in Globalized Economy: Russian Legislation Experience // Lecture Notes in Networks and Systems. 2021. Vol. 160 LNNS. P. 815-821.

20. Murrey J., Bradley H., Creigie W., Tolkien J. Oxford English Dictionary // URL: https://languages.oup.com. 